See discussions, stats, and author profiles for this publication at: https://www.researchgate.net/publication/341228602

\title{
Addressing Service Failure and Recovery in Digital Service Systems: Opportunities and Challenges
}

Article in Journal of Reviews on Global Economics · December 2019

DOI: $10.6000 / 1929-7092.2019 .08 .149$

CITATIONS

4 authors:

João Carlos Gonçalves dos Reis

Universidade Lusófona de Humanidades e Tecnologias

56 PUBLICATIONS 217 CITATIONS

SEE PROFILE

Marlene Amorim

University of Aveiro

142 PUBLICATIONS 444 CITATIONS

SEE PROFILE

Some of the authors of this publication are also working on these related projects:

Project

Artificial Intelligence | Digital Transformation View project

Project Design of Multichannel Services View project
READS

101

Vasco Santos

CiTUR

16 PUBliCATIONS 27 CitATIONS

SEE PROFILE

Nuno Melao

Polytechnic Institute of Viseu

63 PUBLICATIONS 713 CITATIONS

SEE PROFILE 


\title{
Addressing Service Failure and Recovery in Digital Service Systems: Opportunities and Challenges
}

\author{
João Reis ${ }^{1, *}$, Vasco Ribeiro Santos ${ }^{2}$, Marlene Amorim ${ }^{3}$ and Nuno Melão ${ }^{4}$ \\ ${ }^{1}$ Department of Economics, Management and Industrial Engineering and Tourism, GOVCOPP, Aveiro \\ University and ISLA Santarém, Santarém, Portugal \\ ${ }^{2}$ ISLA Santarém, Santarém, and IPT, Tomar, Portugal \\ ${ }^{3}$ Department of Economics, Management and Industrial Engineering and Tourism, GOVCOPP, Aveiro \\ University, Portugal \\ ${ }^{4}$ Department of Management and CISED, School of Technology and Management of Viseu, Polytechnic \\ Institute of Viseu, Viseu, Portugal
}

\begin{abstract}
Digital service systems are changing the world as we know it, enabling companies to embrace new forms of relationship with their customers. The aim of this article is to propose a categorization of service failures in digital service systems and an illustration of recovery solutions based on life situations. Thus, this article used an exploratory case study research conducted in a Portuguese private bank. Data collection involved multiple sources, such as semistructured interviews, customer complaints from an online database, and direct observation. The case revealed that digital service systems are not failure proof and service failures are inevitable. As a result, companies are struggling to consistently maintain high service standards across all channels and, for that purpose, have essentially invested on automated interactions. On the other hand, humanized recovery solutions are expected to enable organizations to make significant progress, including prevention and corrective actions, that will mitigate the perception of poor service delivery. While current studies tend to focus on what is going wrong in digital engagement, researchers have hitherto not investigated sufficiently this digital breakdown and the subsequent recovery solutions.
\end{abstract}

Keywords: Digital service systems, service failure, recovery solutions, channels, case study.

\section{INTRODUCTION}

The service sector has witnessed major digital developments, due to the increasing adoption of automated forms of interactivity in service delivery (Ostrom et al., 2015). Several examples endure in today's market that show the increasing use of automated service interactions. This tendency has been particularly impressive in banking services that are acknowledged as pioneers in the adoption of online technologies, and have paved the way for the multiand omni-channel service experiences that are common today. In this vein, a case from a Portuguese private bank offered a relevant case study to analyse the digitalization of a great extent of service processes, and for enabling new forms of interaction with customers. Currently, a great extent of the customers' engagement with the bank frontline services, including account opening, mainly occurs via automated interactions. Although McKinsey has forecasted that by 2020 machines will manage $85 \%$ of all transactions, at the end of the day, digital, cannot stand alone - it is seamless integration with other channels that wins the

*Address correspondence to this author at the Department of Economics, Management and Industrial Engineering and Tourism, Aveiro University, Campus Universitário de Santiago, 3810-193, Aveiro, Portugal; Tel: 00351234 370 361; Fax: 00351234370 215; E-mail: reis.joao@ua.pt day (Baumgartner, Hatami and Uster, 2016). As realtime interactions with service providers and seamless interactions across multiple channels are a norm rather than the exception, companies are struggling to consistently maintain high service standards through all channels. At the same time, digital service systems are not failure proof, thus service failures have always been inevitable (Hart, Heskett and Sasser, 1990).

Service failure and recovery has been considerably studied in the last two decades (Reis, Amorim and Melão, 2019a). But, despite the insights reached, we still have a limited understanding concerning service failure and recovery on digital service systems. Failure and recovery is expected to enable organizations to make significant progress, including prevention and corrective actions that will mitigate the perception of poor service delivery. In light with the above, we propose a categorization of service failures in digital service systems and an illustration of recovery solutions based on real-life situations. While previous studies are focusing of what is going wrong through digital engagement (Azemi et al., 2019; Rai and Appiah, 2019), researchers have, hitherto, not investigated sufficiently digital services systems breakdowns and the subsequent recovery solutions. 
In the next sections, we provide a review of digital services, service failure and recovery concepts. We then explain the methodological process and the analysis of the case results. We end up with a general discussion and brief conclusions.

\section{THEORETICAL BACKGROUND}

Although service failure and recovery has been extensively studied in the last decades (Sparks and McColl-Kennedy, 2001), there is a limited understanding due the rising of new digital technologies that are virtually transforming everyday business operations in all industry domains (Fitzgerald et al., 2013; Ross et al., 2016). The aforementioned phenomenon is also known as Digital Transformation (DT), and, according to Reis, Amorim, Melão and Matos (2018a, p. 417-18), it has three distinct elements: 1) technological - where DT is based on the use of new digital technologies; 2) organizational since DT requires a change in organizational processes or the creation of new business models; and 3) social - as DT is a phenomenon that is influencing all aspects of human life. The digital transformation changes service systems even further, becoming more and more automated, interactive, open, and learning systems (Böhmann, Leimeister and Möslein, 2018). These service systems are engaging virtual channels (Cortiñas et al., 2010), emphasizing automation (Wirtz et al., 2018) and being integrated in ecosystems (Vargo and Lusch, 2011). All in all, service systems co-create value for all stakeholders in the business ecosystem (Kwan and Min, 2008; Hänninen, Mitronen and Kwan, 2019). The rise of global service-based business models has transformed the way the world works (Maglio, Kwan and Spohrer, 2015); for instance, product-service systems (PSSs)'s popularity has expanded throughout recent years (Haber and Fargnoli, 2019). Fundamental change of a service economy is shifting the research focus from the digitalization of systems to digital service systems (Gou, Li and Dai, 2008a). William et al. (2010) define digital services as services that are arranged through a digital transaction over the Internet, while Wulf, Mettler and Brenner (2017) note that digital services are systems in which human participants and machines carry out activities using information, technology and other resources. Furthermore, Gou et al. (2008a) refers to digital service systems as a trend and a part of the digital society, which invoke digital information, computing, communication and automated technologybased systems that (co)-create the desired outcome (Pakkala and Spohrer, 2019). As the global economy and business are in permanent change, it is likely that applications are integrated within and between organizations, and therefore it is expected that the architecture of services and applications can be combined into an integrated system - digital service systems (Gou, Li, Li and Zhao, 2008b). Nowadays, cities have been evolving as socio-technical and digital service systems, in which people are active actors are the core of all city constituents, where typically care whether their socio-psychological aspects and functional needs are met in a satisfactory manner (Qiu et al., 2017).

Digital societies are supposed to be more efficient when delivering services through multiple digital channels, expecting minor errors or zero defects. However, while companies are struggling to consistently maintain high service standards through all channels, service delivery systems are not fail proof and, thus, it is unlikely that companies are able to avoid failures (Hart et al., 1990; Komunda and Osarenkhoe, 2012). In this context, service failure is defined as any service-related mishaps, real or perceived, that occur during the online/offline service experience with a company (Maxham, 2001). Nowadays, complain management is an essential tool for managers, as service failures are inevitable and recovery encounters encompasses significant challenges (Reis, Amorim and Melão, 2019b).

In the last decades' researchers have proposed several service recovery options (Hazée, Van Vaerenbergh and Armirotto, 2017), such as apologizing, offering compensation and showing empathy or being courteous and respectful (Goodwin and Ross, 1990; Patterson, Cowley and Prasongsukarn, 2006). More collaborative insights propose co-creating service recovery with customers, which refers to the ability to find joint solutions between customer and the service provider (Roggeveen, Tsiros and Grewal, 2012). In general terms, service recovery refers to attempts that companies handle to rectify a service delivery failure (Kelley and Davis, 1994). It seems self-evident that poor service recoveries may cause a negative perception on customers (Maxham, 2001), in contrast to proper recoveries that can restore levels of satisfaction (Goodwin and Ross, 1992) or even it is conceivable that post-failure satisfaction exceeds pre-failure satisfaction in some contexts (McCollough and Bharadwaj, 1992). Present research is increasingly focusing on digital service systems breakdowns and subsequent recovery solutions, rather than focusing only on traditional service delivery. 
Current trends in technology is allowing industries to build services based on artificial intelligence technologies or robotics automating business processes, therefore enhancing service delivery (Sousa, 2015). However, despite the progress in artificial intelligence (Al), few organizations have incorporated successfully Al-related technologies in their service delivery systems. Service robots (e.g. virtual assistants) and automation have evolved from one-function automation to intelligent systems with versatile features, which share the same space and tasks with humans (Savela, Turja and Oksanen., 2017). However, as Wirtz et al. (2018) argues, it seems unlikely that robots will possess the social intelligence and communications skills to deal with complex emotional issues. Therefore, in contexts of higher customer contact, frontline employees can perform complex social/emotional tasks, while service robots are likely to be more successful in activities where greater cognitive/analytic skills are required. In light with the above, it is likely that for simple service failures, bank virtual assistances or automated processes will be enough for troubleshooting. Nevertheless, for failures where a complex social/emotional relationship is needed, frontline employees will be essential to the service recovery process.

\section{METHODOLOGY}

This article uses a qualitative case study research. The authors collected data from a Portuguese private bank, since the banking sector has a long history in adopting new channels in service delivery (Sousa and Amorim, 2009). The data collection centred on customer complaints and involved multiple sources, such as an online database, semi-structured interviews from frontline employees, and direct observations.

The online database, where customer complaints were collected, is known as Complaint Portal, which is operating since June 2009 and currently receives millions of Portuguese every month. According to the official website, $98 \%$ of the visitors' search the website to communicate with other consumers, brands and public entities, as well as to compare brand ranking based on consumer satisfaction index, which reveals that the platform is more than a place to complain, being also a barometer of brands reputation ( $P Q$, 2019). The Complaint Portal is not a mediator between parties (i.e. customer/user and company) and does not have any arbitrary role. Once a user registers a complaint on the website, the Complaint Portal validates the claim and adds it online. Then, the company is notified by electronic mail and it is asked to respond to the claim. Whenever there is a response from the company, the user is notified by electronic mail. Therefore, the Complaint Portal operates as a platform for publishing claims by registered users and facilitates the communication with companies. From January 2011, the unit of analysis (bank) received 445 complaints (PQ, 2019). When compared with similar brands, the bank achieved a satisfaction index of $75.5 \%$. In the last 12 months, the bank exchanged 370 emails with the users of the Complaint Portal, thus, resulting in 83 solved situations. In other words, the service recovery rate is $41.3 \%$ (successful recovery) $(P Q, 2019)$. We analysed 111 complaints from the last 6 months - from January $1^{\text {st }}$ to July $1^{\text {st }}$ of 2019 - with the purpose to categorize the service failures in the past semester.

The interviews as a source of data collection is widely used in case studies and is described as "dynamic meaning-making occasions that result in a collaborative production of knowledge" (Mills, Durepos and Wiebe, 2010, p. 495). We decided to use semistructured interviews as a qualitative data collection strategy. This choice is justified by the intention to conduct a series of predetermined but open-ended questions, with the purpose of having control over the topics, but with no fixed range of responses to each question of the protocol (Given, 2008). We have obtained informed consent in accordance with the procedures of the study protocol (Mack et al., 2005). However, we know that access to sensitive data can cause harm to individuals (National Research Council, 2000), and for that reason, we do not provide any information about key respondents and the respective organization. The research protocol was used to increase reliability of the case study research and it had the purpose of guiding the researchers to carry out data collection (Yin, 2014). We interviewed 11 highly experienced informants from the frontline services of the bank, who were directly involved in the service recovery process. We had access to the bank through an official request, subsequently the respondents were asked to facilitate new interviews, from what is known as snowball sampling (Merriam and Tisdell, 2015), a sampling strategy that fits well the banking industry research (Reis, Amorim and Melão, 2018b). The interviews were very relevant to illustrate possible recovery solutions to the service failures posted on the platform. 
We started collecting data through observation by making informal visits to the bank, to become familiar with the context, the people, and the activities. These informal visits were followed by intense and targeted observations of the phenomenon of interest (Merriam and Tisdell, 2015). Thus, the participants were systematically observed to enable documentation of the real life phenomenon and serendipitous moments. We have structured our observations by creating a checklist based on the following items (5Ws) - Who? What? When? Where? What for? - to register all the events. The field notes were recorded in a research diary (Fisher et al., 2007), that had notes from informal conversations, observation of meetings, and processes (Voss et al., 2002). This information was used, e.g., as generator of questions to be used in an interview (Thorpe and Holt, 2008). Direct observations were typically the secondary source of data collection and they were useful for corroboration and clarification purposes.

We analysed the data through content analysis, which is a well-known "research technique for making replicable and valid inferences from texts (or other meaningful matter) to the context of their use" (Krippendorff, 20018, p.18). Using a computer-assisted qualitative data analysis software NVivo - QSR International, we have analysed the data by clustering the text into hierarchized categories and subcategories (Reis et al., 2019b), so as to identify emerging patters and ideas (Skålén, 2011).

\section{FINDINGS}

This section investigates how the selected unit of analysis is employing its channels to support customer complaints. To the best of our knowledge, this is one of the fewest attempts to offer new insights in the field of digital service systems.

\section{A. Opportunities}

\section{Reducing the Service Failure Recurrence}

The situation that showed a lower recovery satisfaction was identified as sequential service failures. In other words, we have identified customers that had a service failure, which was solved in a first moment, i.e. moment of true (Grönroos, 1988); however, the same typology of failure, occurred again after a short period of time. Which is the same to say, the bank only solved this failure in a temporarily manner, rather than having changed the process. We verified that it was not enough to apologize, listen the customer, or showing empathy (Shapiro and NiemanGonder, 2006), but rather, the bank should search for an effective process change.

If the bank takes the opportunity to improve their processes, it can definitely increase the customers' recovery satisfaction. For instance, if an automatic failure (e.g., unduly charged fee) is quickly recovered, it probably will not have a greater impact on the customer loyalty - standard recovery. Therefore, the recovery satisfaction is due to the bank rapid response, apologizing and service normalization. On the other end, we observed the customer negative feedback was clearly related with service failure recurrence and the discomfort caused by the loss of multichannel freedom. Thus, service normalization is not enough, if the process remains unchanged. This means, the customers were very displeased, not for the failure itself, but for the recurrence of the service failure.

Regarding the aforementioned situation, the digital service systems were not enough to enable the customers' recovery satisfaction; thus, the customers ended up seeking help from frontline employees, in an attempt to re-establish the service delivery personalized recovery. This last note is in line with Wirtz et al. (2018), in the extent that frontline employees are more competent when dealing with complex social/emotional tasks. Indeed, the human factor is known to provide an adequate explanation of the service failure/recovery; but also in aiding the service process changes since these employees are best qualified to provide accurate information about the customers' preferences and expectations.

\section{Relationship within the Business Network}

Another opportunity that was identified during the complaint analysis is the relationship between entities within the same business network. Business networks are companies within the same group of the bank e.g., "Ocidental" - insurance company. In that regard, a real example is provided, as a customer who acquired an Ocidental insurance within the banking infrastructures and, therefore, when something went wrong, it was the bank that received the claim. Solving service failures within the business network turns the process slow, deteriorating the relationship between customers and organizations. In our view, a digital service system is lacking, to mediate these situations, where organizations can collaborate in a faster way, using digital services as an opportunity. 


\section{B. Challenges}

\section{Restoring the Multichannel Freedom}

The origin of multichannel freedom loss is mainly due the lack of circulating information; in this regard, the question which is often addressed to the bank is: "when I cross with a service failure, to what channel should I address the issue?".

Direct observations evidenced that the bank has invested on several automated applications that allow service failure recoveries, i.e. virtual tools, such as: e.g., click to chat, the customer interacts with the bank via Messenger; or click to call, the customer informs the bank though an online channel that wishes to establish a telephone call. However, we verified that often customers feel lost with so much available channels at their disposal, since they are not sure about the channels' attributes. In this regard, frontline employees have suggested additional technologies, such as chatbots or other digital mechanisms that could route customers to the adequate channel within the bank. Thus, digital service systems will probably be adequate to manage and recovery from service failures. This recommendation is in line with Manyika et al. (2017), which argue that automated or semiautomated services (e.g. service robots) are more competent performing complex cognitive and analytical tasks due to underlying computer power.

The analysis of customer complaints evidenced that, when the bank does not provide an adequate response through most convenient channels, some customers started looking for solutions through alternative channels outside of the banks borders. Some alternatives are virtual channels, such as: the complaint portal, customer protection portals or even social networks. In other words, once the multichannel freedom is lost, the client has no longer confidence in a quick reply and looks for alternative channels that put pressure on the service recovery. Therefore, we are confident that customers value certain typologies of virtual channels, but when they do not find solutions in such typologies, they start looking for alternatives outside the bank. The challenge to re-establish the multichannel freedom is of particular interest to customers that are living abroad of Portugal, as they were more vulnerable and, being more dependent on digital service systems to get in touch with the bank, a positive/negative evaluation of the service recovery is likely to be exclusively dependent on a virtual recovery or we could say on the re-establishment of the multichannel freedom.
A third group of customers sought a solution for the service failure recovery within the frontline employees. This attitude most likely happens because the bank is not fully omni-channel. Hence, it is necessary to map the service failure and guide the customers during the recovery process. The frontline employees were once again essential in the recovery process, since they were better prepared to employ immediate corrective actions that mitigated the perception of poor service delivery. This advantage is probably associated to the social/emotional capability of humans when compared with the aforementioned chatbots.

\section{Relationships Outside of the Company's Business Network}

From the data analysis, we identified complains that were not exclusively from the bank responsibility, as these complaints are either due to third parties' relations (e.g. Portuguese tax and customs authority) or regulatory entities (e.g. Bank of Portugal). The complains that involved external organizations were one of the most serious in terms of recovery and received the worst feedback from customers. In the previous section, some service failures were identified as standard (i.e., the moment of true), and the recovery process has been relatively fast and consequently received a better customer feedback - recovery by the firm (Zhu et al., 2013). In this case, customers were not willing to wait for the bank recovery, and digitally connected themselves with the involved external organizations, therefore seeking a recovery through the maximum available channels. The purpose of using digital systems was, on the one hand, to discover where the service failure occurred and to determine the institutional responsibilities, as well as to be part of the service recovery. Consequently, the customers ended up assuming the bank's responsibilities and intervene as a mediator between the bank and the third party in an attempt to regularize the situation - this is known as recovery by the customer (Zhu et al., 2013). In these particular situations, and despite the customer efforts, we acknowledge the existing difficulty in establishing a virtual network with the third party. Therefore, service failures are actually being reclaimed between the trilogy "bank employees - customer - third party", this is also known as joint recovery by the firm and the customer (Zhu et al., 2013). This situation usually results in a time-consuming recovery, and, therefore, developing a greater perceived loss.

\section{Contributions to Practice and Theory}

One of the most relevant queries for practitioners is to find out what motivates customers to lose the 
multichannel freedom, while they search for another channel to interact with the bank. The evidence has shown the lack of multichannel freedom is particularly associated to the bank's inability to reply the customer requests, or simply due to a poor service on the preferred customer channels. The aforementioned situations may illustrate the reasons why digital service systems are so relevant, as these systems offer further channel alternatives. However, too much digital services can also add more entropy into the system, if the channel buddle does not have the same recovery attributes; this situation might lead customer perceived lost or channel cannibalization (Huang et al., 2016). In case of deficient recovery attributes, one could recommend alternative tools to guide customers through the service recovery process (e.g. chatbots) or, to follow an omni-channel strategy, where all the channels can provide a consistent recovery. The bank should also improve its relation within its business network, so that it can take advantage of the digital service systems, to enable faster service recoveries and improving the relationship with the bank stakeholders. To theory, we believe that our article makes it even more evident the opportunity that digital service systems represent, especially in digital transformation contexts.

\section{CONCLUSION}

This research contributed to the service management literature in two ways. First, it provided exploratory evidence related to the classification of service failures (i.e. sequential service failures; failures within business networks; third party service failures) in digital service systems, with the aim of promoting the simplification of recovery procedures. Secondly, in our view, the main results were related to service recovery. In that regard, the results revealed that, in some occasions, frontline employees are better prepared to recovery from service failures, when compared with automated or semi-automated services. Frontlines employees are better prepared to employ immediate corrective actions that mitigate the perception of poor service delivery. This advantage is probably associated with the social/emotional capabilities that frontline employees have when compared to machines. For another side, additional technologies, such as chatbots or other digital mechanism can also route customers to use adequate channels within the bank, while these technologies perform better cognitive and analytical tasks than humans, guiding customers in the quest for the service recovery. This last situation was identified to best suit customers that are dependent on digital service systems, such as emigrants.

This article is not free of limitations, as the data collection was confined to a single Portuguese private bank, and, therefore, this particular study does not have generalization purposes. Due to privacy reasons, it was impossible to map within the bank all the complaints that were posted on the platform; for this reason, the experience of the frontline employees in assisting the researchers evaluating possible recovery solutions was of paramount importance.

We interviewed frontline staff primarily because there were previous studies that showed that customers were turning to physical services when they did not have an answer to their complaints in the online recovery (Reis et al., 2019a). Along these lines, we believe that it would be interesting for researchers to strengthen our results with feedback from online banking employees in order to understand to what extent these employees can streamline customer responses. Additionally, we suggest conducting a intrasectorial study, that is, analysing all complaints from the first day the website - complaint portal is operating across all other national banks.

\section{ACKNOWLEDGEMENTS}

The authors gratefully acknowledge the financial support from the Research Unit on Governance, Competitiveness and Public Policies (GOVCOPP) from Aveiro University - Portugal.

\section{REFERENCES}

Azemi, Y., Ozuem, W., Howell, K. and Lancaster, G. (2019). An exploration into the practice of online service failure and recovery strategies in the Balkans. Journal of Business Research, 94: 420-431. https://doi.org/10.1016/j.jbusres.2018.08.035

Baumgartner, T., Hatami, H. and Uster, M. (2016). Sales growth: five proven strategies from the world's sales leaders. John Wiley \& Sons.

Böhmann, T., Leimeister, J. and Möslein, K. (2018). The new frontiers of service systems engineering. Business and Information Systems Engineering 60(5): 373-375. https://doi.org/10.1007/s12599-018-0553-1

Cortiñas, M., Chocarro, R. and Villanueva, M. (2010). Understanding multi-channel banking customers. Journal of Business Research, 63(11): 1215-1221. https://doi.org/10.1016/j.jbusres.2009.10.020

Fisher, C., Buglear, J., Lowry, D., Mutch, A. and Tansley, C. (2007). Researching and writing a dissertation: a guidebook for business students. Person Education, Harlow.

Fitzgerald, M., Kruschwitz, N., Bonnet, D. and Welch, M. (2013). Embracing digital technology: a new strategic imperative. MIT Sloan Management Review, Research Report. 
Given, L. (2008). The SAGE encyclopaedia of qualitative research methods. Vol. 1\&2, SAGE Publications, Thousand Oaks, CA. https://doi.org/10.4135/9781412963909

Goodwin, C. and Ross, I. (1990). Consumer evaluations of responses to complaints: what's fair and why. Journal of Consumer Marketing, 7(2): 53-61. https://doi.org/10.1108/EUM0000000002519

Goodwin, C. and Ross, I. (1992). Consumer responses to service failure: influence of procedural and interactional fairness perceptions. Journal of Business Research, 25(2): 149-163. https://doi.org/10.1016/0148-2963(92)90014-3

Gou, J., Li, X. and Dai, W. (2008a). On-demand integration of digital service system. In 2008 IEEE International Conference on Service Operations and Logistics, and Informatics (2: 27742778). IEEE. https://doi.org/10.1109/SERVICES-1.2008.38

Gou, J., Li, X., Li, X. and Zhao, P. (2008b). Discipline Comparison of SSME with IS and its education implications. In 2008 IEEE Congress on Services-Part I (57-61). IEEE.

Grönroos, C. (1988). "Service quality": the six criteria of a good perceived service quality. Review of Business, 9(3): 10-13.

Haber, N. and Fargnoli, M. (2019). Prioritizing customer requirements in a product-service system (PSS) context. The TQM Journal, 31(2): 257-273. https://doi.org/10.1108/TQM-08-2018-0113

Hänninen, M., Mitronen, L. and Kwan, S. (2019). Multi-sided marketplaces and the transformation of retail: A service systems perspective. Journal of Retailing and Consumer Services, 49: 380-388. https://doi.org/10.1016/j.jretconser.2019.04.015

Hart, C., Heskett, J. and Sasser, W. (1990). The profitable art of service recovery. Harvard Business Review, 68(4): 148-156.

Hazée, S., Van Vaerenbergh, Y. and Armirotto, V. (2017). Cocreating service recovery after service failure: the role of brand equity. Journal of Business Research, 74: 101-109. https://doi.org/10.1016/j.jbusres.2017.01.014

Huang, L., Lu, X. and Ba, S. (2016). An empirical study of the crosschannel effects between web and mobile shopping channels. Information \& Management, 53: 265-278. https://doi.org/10.1016/j.im.2015.10.006

Kelley, S. and Davis, M. (1994). Antecedents to customer expectations for service recovery. Journal of the Academy of Marketing Science, 22(1): 52-61. https://doi.org/10.1177/0092070394221005

Komunda, M. and Osarenkhoe, A. (2012). Remedy or cure for service failure? Effects of service recovery on customer satisfaction and loyalty. Business Process Management Journal, 18(1): 82-103. https://doi.org/10.1108/14637151211215028

Krippendorff, K. (2018). Content analysis. An introduction to its methodology. SAGE Publications, Thousand Oaks, California.

Kwan, S. and Min, J. (2008). An evolutionary framework of service systems. Journal of Harbin Institute of Technology, 15 (Sup.1): 1-6.

Mack, N., Woodsong, C., Macqueen, K., Guest, G. and Namey, E. (2005). Qualitative research methods: a data collector's field guide. Family Health International, Research Triangle Park, North Carolina.

Maglio, P., Kwan, S. and Spohrer, J. (2015). Commentary-Toward a research agenda for human-centered service system innovation. Service Science, 7(1): 1-10. https://doi.org/10.1287/serv.2015.0091

Manyika, J., Chui, M., Miremadi, M., Bughin, J., George, K., Willmott, P. and Dewhurst, M. (2017). A Future that Works: Automation, Employment, and Productivity, McKinsey Global Institute, San Francisco, CA, available at: www.mckinsey. com/global-themes/digital-disruption/ harnessing-automationfor-a-future-that-works. Accessed: June 23, 2019.
Maxham, J. (2001). Service recovery's influence on consumer satisfaction, positive word-of-mouth, and purchase intentions. Journal of Business Research, 54(1): 11-24. https://doi.org/10.1016/S0148-2963(00)00114-4

McCollough, M. (1995). The recovery paradox: a conceptual model and empirical investigation of customer satisfaction and service quality attitudes after service failure and recovery. Doctoral dissertation, Texas A\&M University, College Station, United States.

Merriam, S. and Tisdell, E. (2015). Qualitative research: a guide to design and implementation. John Wiley \& Sons, California.

Mills, A., Durepos, G. and Wiebe, E. (2010). Encyclopedia of case study research. SAGE Publications, California. https://doi.org/10.4135/9781412957397

National Research Council (2000). Improving access to and confidentiality of research data. Report of a workshop. National Academies Press.

Ostrom, A., Parasuraman, A., Bowen, D., Patrício, L. and Voss, C. (2015). Service research priorities in a rapidly changing context. Journal of Service Research, 18(2): 127-159. https://doi.org/10.1177/1094670515576315

Pakkala, D. and Spohrer, J. (2019). Digital service: technological agency in service systems. In Proceedings of the 52nd Hawaii International Conference on System Sciences. https://doi.org/10.24251/HICSS.2019.229

Patterson, P., Cowley, E. and Prasongsukarn, K. (2006). Service failure recovery: the moderating impact of individual-level cultural value orientation on perceptions of justice. International Journal of Research in Marketing, 23(3): 263277. https://doi.org/10.1016/j.ijresmar.2006.02.004

PQ (2019). About us. https://portaldaqueixa.com/sobre-nos. Accessed: June 23, 2019.

Qiu, R., Badr, Y., Wang, J. and Li, S. (2017). Developing a smart service system to enrich bike riders' experience. In 2nd International Conference on Software, Multimedia and Communication Engineering (SMCE2017). https://doi.org/10.12783/dtcse/smce2017/12468

Rai, D. and Appiah, D. (2019). Competing through online service failures and recovery strategies. In Leveraging ComputerMediated Marketing Environments (266-285). IGI Global. https://doi.org/10.4018/978-1-5225-7344-9.ch013

Reis, J., Amorim, M. and Melão, N. (2019a). Multichannel service failure and recovery in a $\mathrm{O} 2 \mathrm{O}$ era: a qualitative multi-method research in the banking services industry. International Journal of Production Economics, 215: 24-33. https://doi.org/10.1016/.i.jpe.2018.07.001

Reis, J., Amorim, M. and Melão, N. (2019b). Service failure and recovery in technology-based business networks. International Journal of Quality and Service Science, 11(1): 2-15. https://doi.org/10.1108/IJQSS-10-2017-0094

Reis, J., Amorim, M., Melão, N. and Matos, P. (2018a). Digital transformation: a literature review and guidelines for future research. In World Conference on Information Systems and Technologies. Springer, Cham, 411-421. https://doi.org/10.1007/978-3-319-77703-0 41

Reis. J., Amorim, M. and Melão, N. (2018b). Guidelines for qualitative case research in operations management: a banking service industry perspective. In European Conference on Research Methodology for Business and Management Studies. Academic Conferences International Limited, 319-327.

Roggeveen, A., Tsiros, M. and Grewal, D. (2012). Understanding the co-creation effect: when does collaborating with customers provide a lift to service recovery? Journal of the Academy of Marketing Science, 40(6): 771-790. https://doi.org/10.1007/s11747-011-0274-1 
Ross, J., Sebastian, I., Beath, C., Scantlebury, S., Mocker, M., Fonstad, N., Kagan, M., Moloney, K. and Geraghty Krusel, S. (2016). Designing digital organizations. MIT Center for IS Research.

Savela, N., Turja, T. and Oksanen, A. (2018). Social acceptance of robots in different occupational fields: a systematic literature review. International Journal of Social Robotics, 10(4): 493502. https://doi.org/10.1007/s12369-017-0452-5

Shapiro, T. and Nieman-Gonder, J. (2006). Effect of communication mode in justice-based service recovery. Managing Service Quality: An International Journal, 16(2): 124-144. https://doi.org/10.1108/09604520610650619

Skålén, P. (2011). Service marketing control as practice: a case study. Qualitative Market Research: An International Journal, 14(4): 374-390. https://doi.org/10.1108/13522751111163218

Sousa, M. (2015). Emerging technologies as drivers for developing organizational innovation competencies. Economics, 3 (3-4): 97-107. https://doi.org/10.17265/2328-7144/2015.0304.004

Sousa, R. and Amorim, M. (2009). A framework for the design of multichannel services. Project for the Foundation for Science and Technology, under grant number PTDC/GES/68139/2006.

Sparks, B. and McColl-Kennedy, J. (2001). Justice strategy options for increased customer satisfaction in a services recovery setting. Journal of Business Research, 54(3): 209-218. https://doi.org/10.1016/S0148-2963(00)00120-X
Thorpe, R. and Holt, R. (2008). The SAGE dictionary of qualitative management research. London: SAGE Publications. https://doi.org/10.4135/9780857020109

Vargo, S. and Lusch, R. (2011). It's all B2B... and beyond: Toward a systems perspective of the market. Industrial marketing management, 40(2): 181-187. https://doi.org/10.1016/j.indmarman.2010.06.026

Voss, C., Tsikriktsis, N. and Frohlich, M. (2002). Case research in operations management. International Journal of Operations \& Production Management, 22(2): 15-219. https://doi.org/10.1108/01443570210414329

Williams, K., Chatterjee, S. and Rossi, M. (2010). Design of emerging digital services: a taxonomy. In Design Research in Information Systems, Integrated Series in Information Systems, 22, Springer, Boston, MA, 235-253. https://doi.org/10.1007/978-1-4419-5653-8 16

Wirtz, J., Patterson, P., Kunz, W., Gruber, T., Lu, V., Paluch, S. and Martins, A. (2018). Brave new world: service robots in the frontline. Journal of Service Management, 29(5): 907-931. https://doi.org/10.1108/JOSM-04-2018-0119

Wulf, J., Mettler, T. and Brenner, W. (2017). Using a digital services capability model to assess readiness for the digital consumer. MIS quarterly executive, 16(3): 171-195.

Yin, R. (2014). Case study research: design and methods. $5^{\text {th }}$ edition, SAGE Publications, Thousand Oaks.

Zhu, Z., Nakata, C., Sivakumar, K. and Grewal, D. (2013). Fix it or leave it? Customer recovery from self-service technology failures. Journal of Retailing, 89(1): 15-29. https://doi.org/10.1016/j.jretai.2012.10.004

Received on 26-11-2019

Accepted on 17-12-2019

Published on 31-12-2019

DOI: https://doi.org/10.6000/1929-7092.2019.08.149

(c) 2019 Reis et al.; Licensee Lifescience Global.

This is an open access article licensed under the terms of the Creative Commons Attribution Non-Commercial License (http://creativecommons.org/licenses/by-nc/3.0/) which permits unrestricted, non-commercial use, distribution and reproduction in any medium, provided the work is properly cited. 